\title{
Effects of an Enhanced Vitamin A Intake During the Dry Period on Retinoids, Lactoferrin, IGF System, Mammary Gland Epithelial Cell Apoptosis, and Subsequent Lactation in Dairy Cows
}

\author{
G. Puvogel, ${ }^{1, \star}$ C. R. Baumrucker, ${ }^{2}$ H. Sauerwein, ${ }^{3}$ R. Rühl, ${ }^{4,} †$ E. Ontsouka, ${ }^{1}$ \\ H. M. Hammon, ${ }^{1,} \ddagger$ and J. W. Blum ${ }^{1}$ \\ ${ }^{1}$ Division of Nutrition and Physiology, Institute of Animal Genetics, Nutrition and Housing, \\ Vetsuisse Faculty, University of Berne, CH-3012 Berne, Switzerland \\ ${ }^{2}$ Department of Dairy and Animal Science, Penn State University, University Park 16802 \\ ${ }^{3}$ Institute of Physiology, Biochemistry and Animal Hygiene, University of Bonn, D-53115 Bonn, Germany \\ ${ }^{4}$ Institute of Nutritional Science, University of Postdam, D-14558 Potsdam, Germany
}

\begin{abstract}
Studies in vitro show important interactions among vitamin A, lactoferrin, and insulin-like growth factor (IGF) binding proteins (IGFBP) and, thus, the IGF system. As a consequence, mammary gland epithelial cell proliferation and apoptosis during the bovine dry period and potential milk yield may be affected. We have studied effects of feeding vitamin A (550,000 IU/ d) that exceed daily requirements about 8 -fold for up to 2 mo to dairy cows during the dry period on concentrations of retinol and its metabolites in plasma and milk, milk lactoferrin, plasma and milk IGF-I and IGFBP-3, lactoferrin and IGF-I mRNA levels in mammary gland tissue, mammary gland apoptosis, and 100-d milk yield in the ensuing lactation. In the group supplemented with vitamin A, the peripartal decrease of plasma retinol was delayed and attenuated, and colostral retinol plus retinylester concentration was enhanced, but colostral $\beta$-carotene concentration decreased. The retinoic acid isomer 9,13-dicis retinoic acid that coeluted with 13-cis retinoic acid, was the predominant circulating retinoic acid and was higher in GrA than the control group. Plasma IGFBP-3 concentrations were positively correlated with plasma retinol concentrations $(r=0.51)$, but there were no group differences. Numbers of apoptotic epithelial cells in mammary epithelium were higher at drying off and
\end{abstract}

Received August 31, 2004.

Accepted January 13, 2005.

Corresponding author: J. W. Blum; e-mail: juerg.blum@itz. unibe.ch.

*Part of a thesis by G. Puvogel for the D.V.M., accepted by the Vetsuisse Faculty, University of Berne, Switzerland, August 2004.

$\dagger$ Present address: Department of Biochemistry and Molecular Biology, Medical Health Science Center, University of Debrecen, H-4012 Debrecen, Hungary.

$\ddagger$ Present address: Research Institute for Biology of Farm Animals, Nutrition Physiology (Oskar Kellner), Wilhelm-Stahl-Allee 2, D18196 Dummerstorf, Germany. parturition than in the middle of the dry period, coinciding with high concentrations of IGF-I and lactoferrin in mammary secretions. At parturition, numbers of apoptotic cells in mammary gland biopsies in cows supplemented with vitamin A were higher than in control cows. In conclusion, supplementation of dairy cows during the dry period with high amounts of vitamin A did not significantly modify concentrations of lactoferrin, IGFBP-3, and IGF-I in plasma and in mammary secretions, but slightly decreased energy-corrected 100-d milk yield and milk fat yield, possibly because of enhanced apoptic rates of mammary cells.

(Key words: retinoid, lactoferrin, insulin-like growth factor, mammary gland)

Abbreviation key: AP = absorbable protein of the gut, $\mathbf{E C M}=$ energy-corrected milk, $\mathbf{G H}=$ growth hormone, IGFBP = insulin-like growth factor bindingprotein, $\mathbf{L f}=$ lactoferrin, $\mathbf{R A}=$ retinoic acid, atRA = all-trans retinoic acid, 9-cis $\mathbf{R A}=9$-cis retinoic acid, 9,13-dicisRA $=$ 9,13-dicis retinoic acid, 13-cisRA = 13-cis retinoic acid, TUNEL = terminal deoxynucleotidyl transferase (TdT)-mediated X-dUTP nick end labeling.

\section{INTRODUCTION}

A sufficiently long dry period before calving is well known to be a prerequisite for mammary gland regeneration and high milk yields during the ensuing lactation in dairy cows (Sörensen and Enevoldsen, 1991). During the dry period, the bovine mammary gland epithelium involutes and then regenerates (Capuco et al., 2003). Because milk production is dependent on the number of mammary secretory cells and on their synthetic and secretory capacities, the regulation of the mammary epithelial cell population during the dry period has important consequences for milk production and lactation persistency (Capuco et al., 2003). 
The growth hormone (GH)-IGF system has major effects on the mammary gland during various physiological phases (Bauman and Vernon, 1993; Capuco et al., 2003). It consists of 3 ligands (GH, IGF-I, IGF-II), 3 corresponding high-affinity receptors, 6 IGF-binding proteins (IGFBP), and 5 IGFBP-related proteins (Baumrucker and Erondu, 2000). Positive effects of bovine GH on milk yield are in part mediated by IGFI (Bauman and Vernon, 1993). The secretion of IGF-I (and IGF-II) by the bovine mammary gland is enhanced during the dry period (Vega et al., 1991). The IGF stimulate cell proliferation and differentiation and have anti-apoptotic effects (Baumrucker and Erondu, 2000). Their effects are modified by IGFBP that have also IGF-independent effects, as shown for IGFPB-3, the major IGFBP in mammary secretions (Baumrucker and Erondu, 2000). Interestingly, bovine lactoferrin (Lf) binds recombinant human IGFBP-3 and competes with IGF for recombinant human IGFBP-3 binding (Baumrucker and Erondu, 2000). Unlike other milk proteins, Lf is found in milk at high levels after drying off and remains elevated compared with mature milk in postpartum secretions of cows (Welty et al., 1975; Schanbacher et al., 1993). Diverse biological actions of Lf include iron transfer to the neonate, iron scavenging in the neonatal gut, stimulation of intestinal growth, modulation of inflammatory and immune responses, and defense against infection (Lönnerdal and Iyer, 1995; Nuijens et al., 1996). Recently evidence has accumulated that Lf acts as a carrier of IGFBP-3 and allows the translocation of extracellular IGFBP-3 into the nucleus of bovine mammary epithelial cells (Baumrucker and Erondu, 2000). In addition, the transcription of both Lf and IGFBP-3 is influenced by retinoic acid (RA) (Adamo et al., 1992; Shang et al., 1999; Baumrucker and Erondu, 2000). All-trans retinoic acid (atRA) stimulates not only the synthesis and secretion of Lf, but also that of IGFBP3 in bovine mammary epithelial cells (Baumrucker and Erondu, 2000). Furthermore, atRA enhances the nuclear accumulation of Lf and IGFBP-3 in bovine mammary epithelial cells (Baumrucker and Erondu, 2000). Thus, there are mutual interactions among RA, Lf, and IGFBP-3 that may modulate the proliferation and apoptosis of cells, including mammary epithelial cells. This may have important consequences for milk yield. Because the vitamin A status in plasma of dairy cows is highly variable and is in part dependent upon the intake of $\beta$-carotene and vitamin $\mathrm{A}$ and because vitamin $\mathrm{A}$ is excreted by the mammary gland in much higher amounts in the colostral than postcolostral period (Johnston and Chew, 1984), modulations by nutrition of interactions among RA, Lf, and IGFBP-3 can be expected. However, data on interactions among RA,
Lf, and IGFBP-3 so far derive exclusively from in vitro studies. Therefore, the aim of the present study was to test the hypothesis that there are interactions between vitamin A, and especially RA, Lf, and IGFBP-3 and thus IGF-I in vivo and that vitamin A administration enhances milk yield in dairy cows.

\section{MATERIALS AND METHODS}

\section{Animals, Husbandry, and Feeding}

The experimental procedures were approved by the Cantonal Committee for the Permission of Animal Experimentation (Granges-Paccot, Switzerland) and were supervised by the Swiss Federal Veterinary Office (Liebefeld-Berne, Switzerland).

To minimize the influence of individual genetic differences, the effect of vitamin A treatment was compared between 6 pairs of twin Brown Swiss cows that were purchased from dairy herds in Switzerland. One pair was monozygous; the others were twin sisters. Selection criteria were that all cows be clinically healthy, were within the last one-third of their first lactation ( $\geq \mathrm{d} 300$ of lactation), were pregnant, and that the expected calving date of each twin pair did not differ $>6$ wk. Additionally, it was requested that milk yield for each pair of twins did not differ by $>1000 \mathrm{~kg}$ milk/305 d in the first lactation, that clinical mastitis was not evident, and that SCC were always $\leq 200,000 /$ $\mathrm{mL}$ during their first lactation. In fact, milk production during their first lactation ranged from 3594 to 6888 $\mathrm{kg} / 305 \mathrm{~d}$ (305-d standard lactation). The data were supplied by the Brown Cattle Breeder Association (Zug, Switzerland).

The cows were held in a tie barn at the Swiss Federal Research Station (Agroscope, Posieux). Cows had free exercise 5 times/wk for 1 to $2 \mathrm{~h}$ in a courtyard. Throughout the experiment, cows were fed hay of medium quality (4.5 MJ of $\mathrm{NE}_{\mathrm{L}} / \mathrm{kg}$ of $\mathrm{DM}, 73 \mathrm{~g}$ of $\mathrm{CP} / \mathrm{kg}$ of DM, $66 \mathrm{~g}$ of absorbable protein (AP)/kg of DM) twice daily for ad libitum intake during the dry period and good quality hay during the transition period (5.5 MJ of $\mathrm{NE}_{\mathrm{L}} / \mathrm{kg}$ of DM, $144 \mathrm{~g}$ of CP/kg of DM, $90 \mathrm{~g}$ of AP/kg of $\mathrm{DM}$ ) and throughout lactation (5.7 $\mathrm{MJ}$ of $\mathrm{NE}_{\mathrm{L}} / \mathrm{kg}$ of $\mathrm{DM}, 124 \mathrm{~g}$ of $\mathrm{CP} / \mathrm{kg}$ of $\mathrm{DM}, 89 \mathrm{~g}$ of $\mathrm{AP} / \mathrm{kg}$ of $\mathrm{DM}$ ). During the dry period, small amounts of concentrates (8.0 MJ of $\mathrm{NE}_{\mathrm{L}} / \mathrm{kg}$ of DM, $107 \mathrm{~g}$ of CP/ $\mathrm{kg}$ of DM, $85 \mathrm{~g}$ of $\mathrm{AP} / \mathrm{kg}$ of $\mathrm{DM}$ ) were also fed, whose amounts were stepwise increased ( $1 \mathrm{~kg} 2 \mathrm{wk}$ before the expected date of calving; $2 \mathrm{~kg}$ in the last week before parturition). During lactation, concentrates were fed according to yields, and supplementary potatoes were provided. Concentrates were formulated from $33 \%$ barley, $33 \%$ wheat, and $33 \%$ corn. 
Feed consumption was monitored daily by weighing feed offered and left over. Every 2 wk during the dry period and weekly during lactation, BW was determined using a scale. All feeds were analyzed for DM, ash, crude fiber, and CP using standard procedures at the Swiss Federal Research Station (Agroscope Liebefeld-Posieux). Nitrogen-free extract was calculated by difference, and contents of $\mathrm{NE}_{\mathrm{L}}$ and $\mathrm{AP}$ were calculated by regression analysis (Jans and Kessler, 1999).

\section{Experimental Design}

The experiment lasted from the time when the cows were dried off (at d 220 of pregnancy) during their first lactation until d 100 of the second lactation. At drying off, cows received an intramammary injection of Orbenin Extra Dry Cow (Cloxacillin, 600 mg per tube; Pfizer AG, Germany) as standard dry cow therapy. With onset of the dry period, one cow of each twin pair was fed additional vitamin A [RovimixA 500, kindly donated by DSM Nutritional Products, Kaiseraugst (formerly Hoffmann-La Roche, Basle, Switzerland)] that was mixed with concentrates. RovimixA 500 (retinyl acetate) is a product stabilized with ethoxyquin and contains 500,000 IU of vitamin A/g. Supplementation of vitamin A continued until the day of parturition. Supplemented amounts were $880 \mathrm{IU}$ of vitamin A/kg of BW or 550,000 IU of vitamin A per cow (that on average weighed $625 \mathrm{~kg}$ ). The untreated sister was fed the same amounts of concentrates, and served as a control.

\section{Blood Sampling}

Blood samples were taken from the tail vein with evacuated tubes containing EDTA (1.8 $\mathrm{g} / \mathrm{L}$ of blood). Blood samples were obtained weekly from drying off until parturition; immediately (within $1 \mathrm{~h}$ ) after parturition; and on d 2, 5, 30, 60, and 90 of lactation. Retinol, $\beta$-carotene, IGF-I, and IGFBP-3 were determined at the beginning of the dry period (day of drying-off); in the middle of the dry period (on average at $25 \mathrm{~d}$ after drying off); at the end of the dry period (on average at $7 \mathrm{~d}$ before parturition); at parturition; and on $\mathrm{d} 2,5$, and 30 of lactation. Retinyl palmitate, atRA, and the RA isomer 9,13-dicis retinoic acid (9,13-dicisRA), which coeluted with 13-cis retinoic acid (13-cisRA), were measured at the same time as retinol, but not on d 2, 5, and 30 of lactation. Tubes were placed on crushed ice until centrifuged at $1000 \times g$ for $20 \mathrm{~min}$. Supernatants (plasma) were aliquoted and stored at $-20^{\circ} \mathrm{C}$.

\section{Milk Sampling}

Cows were milked twice daily at 0530 and $1630 \mathrm{~h}$. From drying off until parturition, milk samples were taken manually from every quarter at the same time that the blood samples were drawn. Before sampling the teats were wiped to remove gross dirt and subsequently scrubbed with a cotton wool swab soaked in $70 \%$ ethanol and allowed to dry before sampling. Two samples of about $5 \mathrm{~mL}$ were obtained and stored within $2 \mathrm{~h}$ at $-80^{\circ} \mathrm{C}$. After sampling, teats were dipped in a solution containing $10 \mathrm{mg}$ of polyvidonum-iodium $/ \mathrm{mL}$ (Betadine; Provet AG, Lyssach, Switzerland). Lactoferrin was analyzed at drying-off and then weekly until parturition, at parturition and on $\mathrm{d} 2,5,30,60$, and 90 of lactation. Retinol, $\beta$-carotene, retinyl palmitate, atRA, IGF-I, and IGFBP-3 were measured at the beginning, in the middle, at the end of the dry period and in the first milk immediately after parturition at the time of blood sampling.

\section{Mammary Gland Biopsies}

At the start, in the middle (d 21) of the dry period, as well as $1 \mathrm{~d}$ after parturition, mammary biopsies were taken with the Bard Magnum biopsy instrument and Bard Magnum core tissue biopsy needle (C. R. Bard, Inc., Covington, GA) from the right hind quarter. An area of approximately $10 \mathrm{~cm}^{2}$ in the middle of the right hind quarter was shaved and disinfected by washing 3 times alternating with iodine soap (Vetisept, Dr. E. Gräub AG, Niederwangen, Switzerland) and $70 \%$ ethanol. Following local anesthesia with subcutaneus injection of 3 to $5 \mathrm{~mL}$ of lidocain (Lidocain Vet. 2\%; G. Straub \& Co. AG, Uznach, Switzerland), the skin and fascia were penetrated with a sterile trocar $(3.5 \times 80 \mathrm{~mm}$; Provet AG). The biopsy needle was introduced through the trocar to avoid blunting of the needle before getting a biopsy. Five or 6 pieces of mammary tissue, each weighing about $25 \mathrm{mg}$, were taken at each biopsy session. Four biopsies were transferred into 1-mL Nunc Cryo Tubes (Nalge Nunc International, Wiesbaden, Germany), immediately snap-frozen in liquid nitrogen, and kept at $-80^{\circ} \mathrm{C}$ for RNA extraction. The remaining biopsies were stored for approximately $16 \mathrm{~h}$ in ice-cold $4 \%$ paraformaldehyde, then placed for $30 \mathrm{~min}$ in ice-cold 50\% ethanol and were finally stored in $70 \%$ ethanol at $4^{\circ} \mathrm{C}$. These tissue samples were then imbedded in paraffin, and $4-\mu$ sections were cut and mounted on slides for histological and histochemical analyses.

\section{Feed Analyses}

Vitamin $\mathrm{A}$ and $\beta$-carotene in concentrates were determined using a HPLC method with a range above 
$1000 \mathrm{IU}$ of vitamin A/kg. Alkaline saponification, followed by ether extraction of the unsaponifiable compounds, was performed. The ether was evaporated, and the residue dissolved in $\mathrm{n}$-hexane. The extract was injected into a HPLC column filled with silica gel. Retinol, retinyl esters, and $\beta$-carotene were measured fluorometrically. Hay was not analyzed for $\beta$-carotene because it was expected that amounts of $\beta$-carotene were likely relatively low compared with what was ingested with concentrates. Vitamin A was, too, not analyzed in hay because it was not expected to be present. In any case, the same amounts of hay were provided to cows of both groups.

\section{Blood Analyses}

Retinol and $\beta$-carotene concentrations in plasma were determined (Roche, Basle, Switzerland) as described by Vuilleumier et al. (1983). Plasma proteins were precipitated by ethanol, and the compounds of interest were extracted by liquid/liquid extraction with organic solvents. Samples were not saponified. After centrifugation, an aliquot of the organic phase was chromatographed isocratically on a normal phase HPLC system. The identification and quantification of retinol and $\beta$-carotene was done photometrically at wavelenghts of 325 and $450 \mathrm{~nm}$, respectively. In 12 of 240 plasma samples, $\beta$-carotene levels were under the limit of detection $(10 \mu \mathrm{g} / \mathrm{L})$. Samples could be processed without further dilution when concentrations were not $>16,000 \mu \mathrm{g} / \mathrm{L}$. For retinol, all samples were found to be within the described range by Vuilleumier et al. (1983).

Concentrations of plasma retinyl palmitate, atRA, and 9,13-dicisRA/13-cisRA concentrations were measured by a semi-automated system as recently described in detail by Rühl and Schweigert (2003). In short, to $125 \mu \mathrm{L}$ of plasma or milk samples, a 3 -fold excess of isopropanol was added. After 3 min of shaking, the precipitated protein was pelleted by centrifugation. This was followed by extraction of the retinoids using solid-phase extraction cartridges, filled with C2modified silica. The ensuing HPLC analysis for the various retinoids was done in a single run using a multilinear gradient formed with methanol and with aqueous ammonium acetate/methanol (1:1, vol/vol). Retinol and retinyl palmitate were detected and quantified at $326 \mathrm{~nm}$, and RA and oxo-RA were detected and measured at $354 \mathrm{~nm}$ using a diode array detector. The method enabled the quantitative determination of polar and unpolar retinoids, but 9,13-dicisRA [an isomerization product of 9-cis retinoic acid (9-cis RA)] could not be separated in the applied gradient system from 13-cisRA. The recovery of the retinoids was gen- erally between 80 to $90 \%$. The limits of quantification were $1.2 \mu \mathrm{g} / \mathrm{L}$. Standards for the determination of 9cisRA were included in the assay procedure, but 9cisRA in this study was always below the limit of quantification.

Plasma IGF-I concentrations were measured by radioimmunoassay as described by Reist et al. (2003). The IGF-I was separated from IGFBP in plasma and colostrum or milk by extraction with formic acid and ethanol. After extraction, no IGFBP was detected by Western blotting. The extraction procedure was followed by radioimmunoassay. Recombinant human IGF-I (that has the same amino acid sequence as bovine IGF-I) was kindly donated by Novartis AG (formerly CIBA-Geigy AG; Basle) and was used as standard and as $\left[{ }^{125} \mathrm{I}\right]$-labeled ligand. The IGF-I was iodinated by the chloramine-T method, and the radiolabeled IGF-I was separated from damaged products by exclusion chromatography using a Sephadex G-50 column. Polyclonal mouse IGF-I antiserum (that was specific for bovine IGF-I and did not crossreact with IGF-II and insulin) was from C. Baumrucker, Dept. of Dairy and Animal Science, The Pennsylvania State University, University Park. After incubation at $4^{\circ} \mathrm{C}$ for 24 $\mathrm{h}$, bound and free IGF-I were separated by the addition of a second (precipitating) antibody (sheep antimouse immunoglobulin G) and polyethylene glycol, followed by centrifugation at $1500 \times g$ at $4^{\circ} \mathrm{C}$ and aspiration of the supernatant. The radioimmunoassay system was validated according to the recommendadtions of the third Int. Symp. on IGF (Bang et al., 1995). Diluted IGF extracts from plasma and colostrum or milk paralleled the standard curve. Intra- and interassay coefficients of variation were $<10$ and $15 \%$, respectively.

Plasma IGFBP-3 was determined with an ELISA as described by Hennies and Sauerwein (2003). Antisera were raised in crossbreed rabbits immunized with 200 $\mu \mathrm{g}$ of a synthetic peptide based on the bovine IGFBP-3 amino acid sequence (STENQAGPSTHRVPVSKY) bound to $400 \mu \mathrm{g}$ of keyhole limpet hemocyanin (Sigma, St. Louis, MO) with glutardialdehyde. The antigen was subsequently emulsified in complete Freund's adjuvant for the first immunization and in incomplete Freund's adjuvant for booster immunizations. For tracer synthesis, the purified IGFBP-3 was biotinylated. Microtiter plates were coated with sheep IgG (containing $150 \mathrm{ng}$ of antirabbit-Fc fragment antibodies). After coating with casein, the plates were washed, filled with assay buffer, and stored at $4^{\circ} \mathrm{C}$ for up to several weeks without appreciable loss of sensitivity. The IGFBP-3 standards, plasma or milk samples, were prediluted $1 / 10$ to $1 / 100$ in pooled goat serum depending on IGFBP-3 content. Standards or samples ( $50 \mu \mathrm{L}$ ) were pipetted into the wells of the assay plates, 
and antiserum $(50 \mu \mathrm{L}$; diluted $1 / 40,000$ with assay buffer) was added. After preincubation at $4^{\circ} \mathrm{C}$ for 20 $\mathrm{h}$, biotinylated IGFBP-3 $(50 \mu \mathrm{L})$ in pooled goat serum were added, and the mixture was incubated at $4^{\circ} \mathrm{C}$ for another $24 \mathrm{~h}$ and then decanted. A streptavidinperoxidase conjugate solution $(100 \mu \mathrm{L})$ was added per well. The plates were incubated at $4^{\circ} \mathrm{C}$ for $30 \mathrm{~min}$ and, after 5 washes, the wells were filled with $150 \mu \mathrm{L}$ of substrate solution containing tetramethylbenzidine. The reaction was stopped by the addition oxalic acid, and the color development was determined photometrically at $450 \mathrm{~nm}$ (with $630 \mathrm{~nm}$ as reference) on a microtiter plate reader. The antiserum was highly specific for bovine IGFBP-3. No major cross-reaction could be detected with IGFBP-3 from horse, pig, chicken, goats, and sheep. Neither human IGF-I, human IGF2, nor bovine IGFBP-2 (GroPep Limited, Adelaide, Australia) at concentrations up to $50 \mathrm{ng}$ per well nor bovine lactoferrin up to $50 \mu \mathrm{g}$ per well showed a crossreaction. The measuring range for a sample diluted 1/ 10 was between 50 and $1000 \mathrm{ng}$ of IGFBP-3/mL of serum or milk. Recovery of 3 different IGFBP-3 concentrations added to 4 samples of bovine serum and milk was on average $97.3 \%$ for serum and $100.1 \%$, respectively, for milk. Intra- and interassay coefficients of variation ranged from 6 to $9 \%$.

\section{Milk Analyses}

Once weekly during lactation, a composite milk sample (from all 4 quarters) was taken from each cow to determine by standard methods crude fat, $\mathrm{CP}$, and lactose content by infra-red spectroscopy (Milko-Scan 605; Foss Electric, Hillerød, Denmark) and SCC by the fluoro-opto-electronic method (Fossomatic; Foss Electric) at the laboratory of the Swiss Holstein Breeder Association (Grangeneuve, Posieux, Switzerland). The energy-corrected milk (ECM) was calculated as [ $(0.038$ $\times \mathrm{g}$ of crude fat $+0.024 \times \mathrm{g}$ of $\mathrm{CP}+0.017 \times \mathrm{g}$ of lactose) $\times \mathrm{kg}$ of milk] $\div 3.14$ (Jans and Kessler, 1999). Lactation persistency was calculated as the ratio of average milk yield in wk 13, 14, and 15 relative to average milk yield in wk 3,4 , and $5(=100 \%)$ and was expressed as a percentage.

Retinol and $\beta$-carotene were analyzed by HPLC (Roche, Basle, Switzerland) as described by Zinsstag et al. (2002). The samples were saponified, and values of retinol included values of retinyl esters. Retinyl palmitate, atRA and 9,13-dicisRA/13-cisRA milk concentrations were additionally measured as recently described for plasma by Rühl and Schweigert (2003). The method, orginially designed for measurements of retinoids in plasma, has been shown to be applicable for colostrum and milk using the same sample prepa- ration, extraction procedures, and analytical procedures and resulted in comparable recovery rates as in blood plasma. The quanitification limit was $1.2 \mu \mathrm{g} / \mathrm{L}$. In 5 of 48 samples, atRA concentrations were slightly under the quantification limit. Concentrations of 9cis RA and 9,13-dicisRA/13-cis were always below the quantification limit.

The Lf was measured as described by an enzyme immunoassay (Welty et al., 1975). The IGF-I concentrations were measured by radioimmunoassay as described for blood plasma in casein-deprived colostrum or milk serum, obtained by treatment with rennin and followed by centrifugation to remove casein (Ronge and Blum, 1988). The IGFBP-3 was determined by an ELISA as described previously for plasma (Hennies and Sauerwein, 2003).

\section{Evaluation of Apoptosis}

In biopsies of mammary glands, the apoptotic cells were visualized using a terminal deoxynucleotidyl transferase (TdT)-mediated X-dUTP nick end labeling (TUNEL) assay. After dewaxing, rehydration, and treatment with proteinase $\mathrm{K}(10 \mu \mathrm{g} / \mathrm{mL}$; Roche Diagnostics, Rotkreuz, Switzerland) for $10 \mathrm{~min}$ at $37^{\circ} \mathrm{C}$, the slides were incubated with the TUNEL reaction mixture (Roche) for $1 \mathrm{~h}$ at $37^{\circ} \mathrm{C}$. Terminal deoxynucleotidyl transferase from calf thymus (Roche) was used to label DNA strand breaks of apoptotic cells, and fluorescein-12-2'-deoxyuridine-5'-triphosphate (Roche) to visualize the labeled cells. Then, the slides were counterstained with Hoechst reagent (DAPI, D9542, Sigma) to label DNA and, thus, the cell nucleus and mounted for fluorescent microscopy with Fluorescent Mounting Medium (DAKO, Glostrup, Denmark). Slides for detection of apoptotic cells were examined by fluorescent microscopy. Three slides were prepared for each cow representing the different timepoints (beginning, middle of the dry period, and parturition). One representative photograph was taken from every slide with a digital camera. Digital photographs were evaluated on a computer using a graphic program (Corel Draw 9, Version 9.337, Corel Corporation, Ottawa, Ontario, Canada). Each picture was completely filled with mammary gland tissue. The relative amounts of tissues were quantified in each picture at 25,50 and $75 \%$ along 3 horizontal and 3 vertical lines. This provided a method to determine the relative amounts of epithelial tissue, stromal (connective) tissue, and alveolar lumen. For quantification of apoptotic cells, TUNEL-positive cells in the epithelium and stroma were counted. One picture on the computer screen represented an actual area of $1.635 \mathrm{~mm}^{2}$ of mammary gland tissue. By analyzing 3 photographs, 
it was possible to evaluate an area of $4.9 \mathrm{~mm}^{2}$ of mammary gland tissue at each time point. When TUNELpositive cells were counted and the proportions of epithelial and stromal tissue and alevolar lumina were determined, the number of positive cells $/ \mathrm{mm}^{2}$ could be calculated.

\section{Total RNA Extraction and Reverse Transcription PCR}

Total RNA was extracted from $25 \mathrm{mg}$ of mammary gland biopsies using $0.5 \mathrm{~mL}$ of TRIzol reagent (Gibco BRL, Basle, Switzerland), and the concentration of recovered RNA was measured as described previously (Ontsouka et al., 2004). One microgram of total RNA was reverse transcribed into cDNA using $100 \mathrm{pmol}$ of random hexamer primer as described previously (Ontsouka et al., 2004). The details of procedures for the design of primers used in the present study to measure mRNA levels of Lf, IGF-I and ubiquitin (used as housekeeping gene) have been described previously (Pfaffl et al., 2002, 2003). The PCR quantification was performed with the LightCycler System (Roche Molecular Biochemicals, Rotkreuz, Switzerland) using software package 3.3 (Roche) and using SYBR Green I (a double-stranded DNA-binding dye). Conditions used for PCR amplification of IGF-I and ubiquitin mRNA were as described (Pfaffl et al., 2002; Ontsouka et al., 2004). The mRNA amplification of IGF-I, Lf, and ubiquitin was performed in 3 PCR runs. For PCR amplification of IGF-I and Lf mRNA, each run included a negative control (water), an internal control (pooled cDNA), and cDNA of 4 cows of different lactational stages measured in duplicate. The internal control was used to correct for interassay variations between runs.

Obtained values of Lf and IGF-I were corrected for cDNA variations among samples dependent on corresponding expression levels of the housekeeping gene (ubiquitin in the present study) as recently described (Ontsouka et al., 2004).

\section{Statistical Analyses}

Values for zootechnical parameters, blood and milk traits, as well as mRNA for Lf and IGF-I, histomorphometrical traits, and number of apoptotic cells in mammary tissues were expressed as means \pm SEM. Since the data were normally distributed, the results were evaluated using the RANDOM and REPEATED methods of the MIXED procedure (SAS Inst., Inc., Cary, $\mathrm{NC})$. Vitamin A treatment and time were used as fixed effects, and the individual cows were used as random effects. For the evaluation of differences in treatment with regard to different time, the treatment $\times$ time interactions were included in the model. Treatment and time differences were compared by LSD $t$-test ( $P$ $<0.1$ for a trend and $P<0.05$ for significant difference). Treatment effects on persistence of lactation were evaluated using the general linear model procedure, and means were separated by LSD $t$-test $(P<0.05)$. For correlations of blood and milk parameters with apoptotic cells, the PROC CORR procedure of the SAS program was used.

\section{RESULTS}

\section{BW, DM, NE $\mathrm{L}_{\mathrm{L}}, \mathrm{CP}$ and AP Intakes, and Milk Yield}

The BW increased $(P<0.001)$ in both groups from drying off until calving, abruptly decreased after calving and then decreased more slowly up to wk 8 to 10 after parturition (Table 1 ). Intakes of $\mathrm{DM}, \mathrm{NE}_{\mathrm{L}}$, and CP increased $(P<0.001)$ during the dry period and up to 6 wk after parturition, but BW and intakes of DM, $\mathrm{NE}_{\mathrm{L}}$, and $\mathrm{CP}$ were not significantly different between the group supplemented with vitamin A and the control group. In both groups, the energy balances were positive during the dry period (means: $14.7 \pm 2.8$ and $20.8 \pm 4.9 \mathrm{MJ}$ of $\mathrm{NE}_{\mathrm{L}} / \mathrm{d}$ in the group supplemented with vitamin $\mathrm{A}$ and the control group, respectively), but negative from parturition until 4 to $6 \mathrm{wk}$ of lactation (means: $-8.9 \pm 3.5$ and $-6.3 \pm 4.9 \mathrm{MJ}$ of $\mathrm{NE}_{\mathrm{L}} / \mathrm{d}$ in the group supplemented with vitamin A and the control group, respectively). Protein balances were positive during the dry period (means: $673 \pm 100$ and $823 \pm$ $173 \mathrm{~g}$ of CP in the group supplemented with vitamin A and the control group, respectively; means: $370 \pm 17$ and $420 \pm 69 \mathrm{~g}$ of AP/d in the group supplemented with vitamin $\mathrm{A}$ and the control group, respectively) and during lactation (means: $618 \pm 89$ and $555 \pm 53 \mathrm{~g}$ of $\mathrm{CP} / \mathrm{d}$ in the group supplemented with vitamin $\mathrm{A}$ and the control group, respectively; means: $158 \pm 62$ and $122 \pm 31 \mathrm{~g}$ of $\mathrm{AP} / \mathrm{d}$ in the group supplemented with vitamin A and the control group, respectively), except in wk 1 of lactation (means: $52 \pm 134$ and $255 \pm 114 \mathrm{~g}$ of $\mathrm{CP} / \mathrm{d}$ in the group supplemented with vitamin $\mathrm{A}$ and the control group, respectively; means: $-168 \pm 142$ and $-99 \pm 76 \mathrm{~g}$ of $\mathrm{AP} / \mathrm{d}$ in the group supplemented with vitamin A and the control group, respectively). Energy and protein balances were not significantly different between the group supplemented with vitamin A and the control group.

In both groups, ECM yields rapidly increased $(P<$ 0.001 ) to peaks in wk 5 to 6 of lactation (Table 2). Cows in the control group had a higher lactation persistency than cows supplemented with vitamin A (means: 89.8 \pm 3.6 and $78.9 \pm 2.7 \%$, respectively; $P<0.05$ ) and 100 d ECM yield was higher $(P<0.01)$ in the control group than in the group supplemented with vitamin A (2703 
Table 1. Body weight and daily intake of DM, energy, and CP. ${ }^{1}$

\begin{tabular}{|c|c|c|c|c|c|c|c|c|c|c|c|c|c|}
\hline \multirow[b]{3}{*}{ Trait } & \multirow[b]{3}{*}{ Group } & \multirow{2}{*}{\multicolumn{3}{|c|}{ Dry period }} & \multirow{2}{*}{\multicolumn{6}{|c|}{ Week in lactation }} & \multicolumn{3}{|c|}{ ANOVA $(P)$} \\
\hline & & & & & & & & & & & \multirow{2}{*}{$\begin{array}{l}\text { Treat- } \\
\text { ment } \\
\text { (Trt) }\end{array}$} & \multirow[b]{2}{*}{ Time } & \multirow{2}{*}{$\begin{array}{l}\text { Trt }> \\
\text { time }\end{array}$} \\
\hline & & Beginning $^{2}$ & Middle $^{3}$ & End $^{4}$ & 1 & 3 & 6 & 9 & 12 & 15 & & & \\
\hline BW, kg & $\begin{array}{l}\text { Supplemented } \\
\text { Control }\end{array}$ & $\begin{array}{l}624 \pm 22 \\
609 \pm 11\end{array}$ & $\begin{array}{l}653 \pm 17 \\
654 \pm 8\end{array}$ & $\begin{array}{l}667 \pm 21 \\
675 \pm 10\end{array}$ & $\begin{array}{l}616 \pm 20 \\
603 \pm 8\end{array}$ & $\begin{array}{l}597 \pm 18 \\
595 \pm 9\end{array}$ & $\begin{array}{l}593 \pm 16 \\
573 \pm 11\end{array}$ & $\begin{array}{l}587 \pm 19 \\
575 \pm 5\end{array}$ & $\begin{array}{l}594 \pm 20 \\
590 \pm 6\end{array}$ & $\begin{array}{l}595 \pm 24 \\
593 \pm 10\end{array}$ & $\mathrm{NS}^{5}$ & 0.001 & NS \\
\hline DMI, kg & $\begin{array}{l}\text { Supplemented } \\
\text { Control }\end{array}$ & $\begin{array}{l}9.4 \pm 0.2 \\
8.9 \pm 04\end{array}$ & $\begin{array}{l}10.8 \pm 0.4 \\
10.3 \pm 0.7\end{array}$ & $\begin{array}{l}13.8 \pm 0.3 \\
13.3 \pm 0.7\end{array}$ & $\begin{array}{l}13.9 \pm 0.8 \\
11.7 \pm 1.2\end{array}$ & $\begin{array}{l}18.6 \pm 0.9 \\
18.7 \pm 1.0\end{array}$ & $\begin{array}{l}21.3 \pm 1.0 \\
21.1 \pm 1.2\end{array}$ & $\begin{array}{l}20.7 \pm 0.6 \\
20.5 \pm 1.0\end{array}$ & $\begin{array}{l}19.6 \pm 0.9 \\
20.4 \pm 0.6\end{array}$ & $\begin{array}{l}20.4 \pm 0.8 \\
20.9 \pm 0.6\end{array}$ & NS & 0.001 & NS \\
\hline $\begin{array}{l}\text { Energy } \\
\text { intake, MJ } \\
\text { of } \mathrm{NE}_{1} / \mathrm{d}\end{array}$ & $\begin{array}{l}\text { Supplemented } \\
\text { Control }\end{array}$ & $\begin{array}{l}44 \pm 1 \\
42 \pm 2\end{array}$ & $\begin{array}{l}53 \pm 3 \\
59 \pm 5\end{array}$ & $\begin{array}{l}79 \pm 2 \\
76 \pm 4\end{array}$ & $\begin{array}{l}86 \pm 5 \\
73 \pm 7\end{array}$ & $\begin{array}{l}117 \pm 6 \\
119 \pm 6\end{array}$ & $\begin{array}{l}137 \pm 8 \\
133 \pm 8\end{array}$ & $\begin{array}{l}130 \pm 4 \\
129 \pm 6\end{array}$ & $\begin{array}{l}123 \pm 7 \\
129 \pm 4\end{array}$ & $\begin{array}{l}127 \pm 6 \\
132 \pm 4\end{array}$ & NS & 0.001 & NS \\
\hline $\begin{array}{l}\text { CP intake, } \\
\mathrm{kg} / \mathrm{d}\end{array}$ & $\begin{array}{l}\text { Supplemented } \\
\text { Control }\end{array}$ & $\begin{array}{l}0.9 \pm 0.01 \\
0.9 \pm 0.03\end{array}$ & $\begin{array}{l}1.2 \pm 0.10 \\
1.3 \pm 0.17\end{array}$ & $\begin{array}{l}2.1 \pm 0.05 \\
2.1 \pm 0.09\end{array}$ & $\begin{array}{l}2.0 \pm 0.11 \\
1.7 \pm 0.17\end{array}$ & $\begin{array}{l}2.5 \pm 0.13 \\
2.6 \pm 0.14\end{array}$ & $\begin{array}{l}3.4 \pm 0.54 \\
3.1 \pm 0.32\end{array}$ & $\begin{array}{l}2.7 \pm 0.08 \\
2.7 \pm 0.12\end{array}$ & $\begin{array}{l}2.6 \pm 0.12 \\
2.6 \pm 0.08\end{array}$ & $\begin{array}{l}2.7 \pm 0.11 \\
2.7 \pm 0.09\end{array}$ & NS & 0.001 & NS \\
\hline
\end{tabular}

${ }^{1}$ Values are means \pm SEM; $n=6$ per group.

${ }^{2}$ Day of drying off.

${ }^{3}$ On average, $25 \mathrm{~d}$ after drying off.

${ }^{4}$ On average, $7 \mathrm{~d}$ before parturition.

${ }^{5} P>0.05$.

Table 2. Weekly energy-corrected milk (ECM) yield and milk fat, protein, and lactose content. ${ }^{1}$

\begin{tabular}{|c|c|c|c|c|c|c|c|c|c|c|c|c|c|}
\hline \multirow[b]{3}{*}{ Trait } & \multirow[b]{3}{*}{ Group } & \multirow{2}{*}{\multicolumn{9}{|c|}{ Week in lactation }} & \multicolumn{3}{|c|}{ ANOVA $(P)$} \\
\hline & & & & & & & & & & & \multirow{2}{*}{$\begin{array}{l}\text { Treatment } \\
\text { (Trt) }\end{array}$} & \multirow[b]{2}{*}{ Time } & \multirow{2}{*}{$\begin{array}{l}\text { Trt } \times \\
\text { time }\end{array}$} \\
\hline & & 1 & 2 & 3 & 5 & 7 & 9 & 11 & 13 & 15 & & & \\
\hline ECM, kg & $\begin{array}{l}\text { Supplemented } \\
\text { Control }\end{array}$ & $\begin{array}{l}132 \pm 8 \\
143 \pm 16\end{array}$ & $\begin{array}{l}197 \pm 7 \\
165 \pm 30\end{array}$ & $\begin{array}{l}199 \pm 10 \\
198 \pm 10\end{array}$ & $\begin{array}{l}205 \pm 11 \\
195 \pm 9\end{array}$ & $\begin{array}{l}198 \pm 10 \\
191 \pm 10\end{array}$ & $\begin{array}{l}184 \pm 8 \\
194 \pm 8\end{array}$ & $\begin{array}{l}179 \pm 12 \\
187 \pm 9\end{array}$ & $\begin{array}{l}164 \pm 8^{\mathrm{x}} \\
191 \pm 7^{\mathrm{y}}\end{array}$ & $\begin{array}{l}160 \pm 12 \\
181 \pm 9\end{array}$ & $\mathrm{NS}^{2}$ & 0.001 & 0.01 \\
\hline Fat, g/L & $\begin{array}{l}\text { Supplemented } \\
\text { Control }\end{array}$ & $\begin{array}{l}39.8 \pm 2 \\
38.9 \pm 3\end{array}$ & $\begin{array}{l}38.5 \pm 1 \\
41.4 \pm 3\end{array}$ & $\begin{array}{l}36.7 \pm 2 \\
38.2 \pm 1\end{array}$ & $\begin{array}{l}38.3 \pm 2 \\
37.1 \pm 1\end{array}$ & $\begin{array}{l}36.3 \pm 2 \\
38.0 \pm 1\end{array}$ & $\begin{array}{l}36.7 \pm 2 \\
40.2 \pm 1\end{array}$ & $\begin{array}{l}37.5 \pm 2 \\
37.3 \pm 1\end{array}$ & $\begin{array}{l}36.4 \pm 1^{\mathrm{x}} \\
41.2 \pm 1^{\mathrm{y}}\end{array}$ & $\begin{array}{l}42.7 \pm 2 \\
39.8 \pm 1\end{array}$ & NS & NS & 0.1 \\
\hline Protein, g/L & $\begin{array}{l}\text { Supplemented } \\
\text { Control }\end{array}$ & $\begin{array}{l}40.8 \pm 2 \\
40.0 \pm 1\end{array}$ & $\begin{array}{l}35.0 \pm 1 \\
36.6 \pm 2\end{array}$ & $\begin{array}{l}32.8 \pm 1 \\
33.5 \pm 2\end{array}$ & $\begin{array}{l}31.5 \pm 1 \\
31.6 \pm 1\end{array}$ & $\begin{array}{l}33.0 \pm 1 \\
30.9 \pm 1\end{array}$ & $\begin{array}{l}33.0 \pm 1 \\
32.6 \pm 1\end{array}$ & $\begin{array}{l}33.6 \pm 1 \\
33.9 \pm 1\end{array}$ & $\begin{array}{l}35.5 \pm 1 \\
33.9 \pm 1\end{array}$ & $\begin{array}{l}32.7 \pm 2 \\
34.3 \pm 1\end{array}$ & NS & 0.001 & NS \\
\hline Lactose, $\mathrm{g} / \mathrm{L}$ & $\begin{array}{l}\text { Supplemented } \\
\text { Control }\end{array}$ & $\begin{array}{l}50.4 \pm 1 \\
50.7 \pm 1\end{array}$ & $\begin{array}{l}52.4 \pm 1 \\
51.4 \pm 1\end{array}$ & $\begin{array}{l}52.3 \pm 1 \\
51.6 \pm 1\end{array}$ & $\begin{array}{l}52.1 \pm 1 \\
51.3 \pm 1\end{array}$ & $\begin{array}{l}52.2 \pm 1 \\
51.4 \pm 1\end{array}$ & $\begin{array}{l}51.7 \pm 1 \\
51.4 \pm 1\end{array}$ & $\begin{array}{l}49.1 \pm 2 \\
51.4 \pm 1\end{array}$ & $\begin{array}{l}51.8 \pm 1 \\
51.6 \pm 1\end{array}$ & $\begin{array}{l}50.9 \pm 1 \\
50.2 \pm 1\end{array}$ & NS & 0.01 & NS \\
\hline
\end{tabular}

${ }^{\mathrm{x}, \mathrm{y}}$ Means with different superscripts are significantly different $(P<0.05)$ between supplemented and control group for each trait

${ }^{1}$ Values are means $\pm \mathrm{SE} ; \mathrm{n}=6$ per group.

${ }^{2} P>0.05$. 
\pm 95 and $2596 \pm 111 \mathrm{~kg} / 100 \mathrm{~d}$, respectively). Fat content did not significantly change, but tended to be higher $(P<0.1)$ in the control group than in the group supplemented with vitamin A and fat yield was significantly higher in controls than in the group supplemented with vitamin A $(105.5 \pm 3.5$ and $100.4 \pm 3.7 \mathrm{~kg} / 100$ $\mathrm{d}$, respectively; $P<0.05)$. Milk protein concentration rapidly decreased $(P<0.001)$ after the onset of lactation to a nadir in wk 5 or 6 and then increased $(P<$ 0.001 ), but there were no significant group differences in protein concentration and protein yields $(89.7 \pm 4.5$ and $89.6 \pm 6.0 \mathrm{~kg} / 100 \mathrm{~d}$, in the group supplemented with vitamin $\mathrm{A}$ and the control group, respectively). Milk lactose concentration rapidly increased $(P<$ 0.005 ) after the onset of lactation especially in cows supplemented with vitamin A, but there were no significant group differences in lactose concentrations and in lactose yields $(133.8 \pm 5.5$ and $138.6 \pm 4.6 \mathrm{~kg} /$ $100 \mathrm{~d}$ in the group supplemented with vitamin $\mathrm{A}$ and the control group, respectively).

Mean SCC from wk 1 to 15 in the group supplemented with vitamin A and the control group (285,000 $\pm 140,000$ and $118,000 \pm 51,000$ cells $/ \mathrm{mL}$, respectively) did not change significantly over time, and there were no significant treatment effects.

\section{Concentrations of $\beta$-Carotene, Retinol, Retinol Metabolites, IGF-I, and IGFBP-3 in Plasma}

Concentrations of $\beta$-carotene (Table 3 ) were affected by time and markedly decreased $(P<0.001)$ during the dry period in both groups, followed by a slow rise $(P<0.001)$ up to d 30 of lactation, but there were no significant group differences.

Concentrations of retinol (Table 3) were affected by vitamin A treatment and time, and there was a significant treatment $\times$ time interaction. Concentrations in cows supplemented with vitamin A remained stable until the end of the dry period, decreased $(P<0.001)$ on $\mathrm{d} 1$ of lactation, and then slowly increased up to $\mathrm{d} 30$ of lactation. Concentrations in control cows decreased already at the end of the dry period and further decreased on $\mathrm{d} 1$ of lactation, followed by a slow increase $(P<0.001)$ until d 30 of lactation. At the end of the dry period and on $\mathrm{d} 1,2$, and 5 of lactation, concentrations were higher $(P<0.05)$ in cows supplemented with vitamin A than in control cows. Plasma retinol and plasma $\beta$-carotene concentrations were positively correlated $(\mathrm{r}=0.59 ; P<0.001)$.

Concentrations of retinyl palmitate (Table 3) were affected by time and during the dry period transiently increased $(P<0.01)$ in cows supplemented with vita$\min \mathrm{A}$ and then decreased to the lowest levels on $\mathrm{d} 1$ of lactation, whereas concentrations in control cows

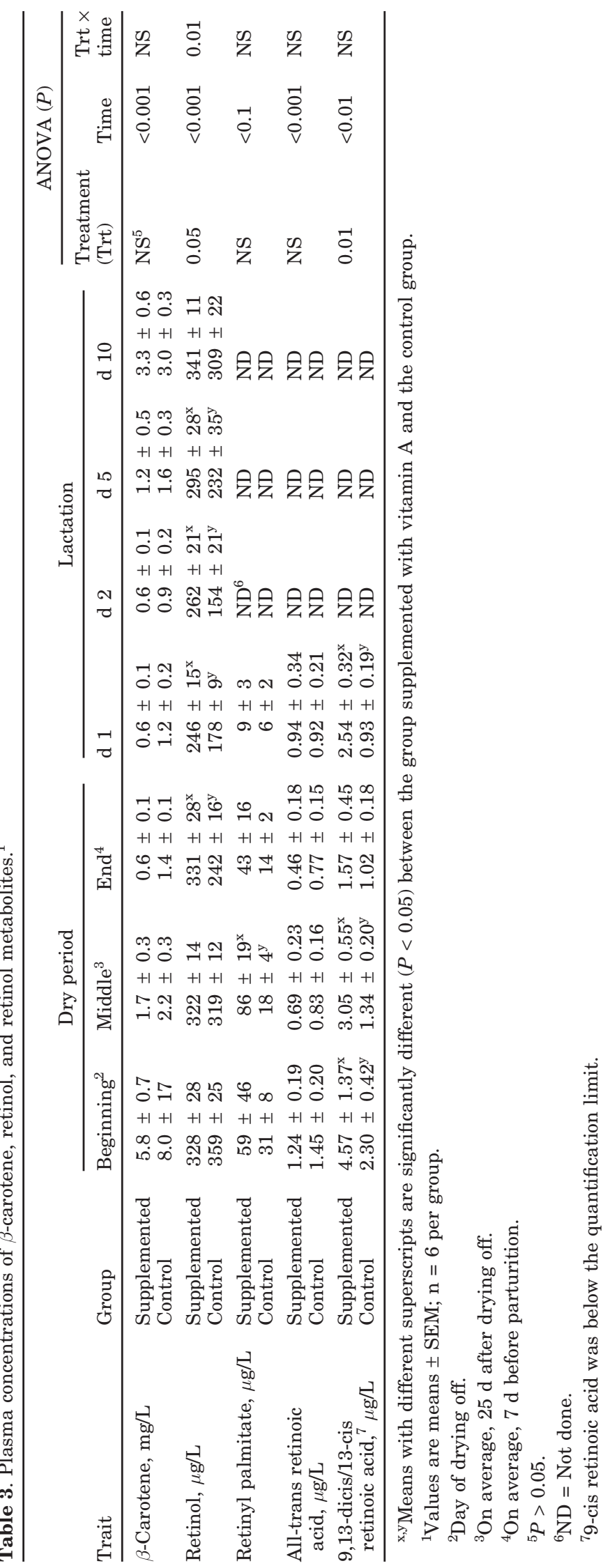


steadily decreased $(P<0.1)$ during the dry period until $\mathrm{d} 1$ of lactation. There were no significant overall differences between cows supplemented with vitamin A and control cows.

Concentrations of atRA (Table 3) in both groups decreased $(P<0.001)$ up to the end of the dry period and then increased $(P<0.001)$ on $d 1$ of lactation, but there were no significant group differences.

Concentrations of 9,13-dicisRA/13-cisRA (Table 3) were affected by time and by treatment and decreased $(P<0.005)$ up to the end of the dry period in cows supplemented with vitamin A or on d 1 of lactation in control cows. Concentrations were higher $(P<0.01)$ in cows supplemented with vitamin A than in control cows during the entire dry period as well as on $d 1$ of lactation.

Concentrations of IGF-I (Table 4) were affected by time and transiently increased $(P<0.001)$ in the middle of the dry period and then decreased $(P<0.001)$ and reached lowest levels on $d 2$ and 5 of lactation, followed by a slow rise until d 30 of lactation, but there were no significant group differences.

Concentrations of IGFBP-3 (Table 4) were affected by time, decreased $(P<0.001)$ during the dry period, and reached lowest levels on $\mathrm{d} 1$ of lactation and then slowly increased $(P<0.001)$, but there were no significant group differences. Concentrations were positively correlated with plasma concentrations of IGF-I ( $\mathrm{r}=$ $0.66 ; P<0.001)$ and retinol $(\mathrm{r}=0.51 ; P<0.001)$.

\section{Concentrations of $\beta$-Carotene, Retinol, Retinol Metabolites, Lactoferrin, IGF-I, and IGFBP-3 in Mammary Secretions}

Concentrations of $\beta$-carotene (Table 5) were affected by vitamin A treatment and by time, and there were significant time $\times$ treatment interactions. Concentrations increased $(P<0.001)$ in both groups during the dry period and reached maximum levels on $d 1$ of lactation. Concentrations during the dry period tended to be higher $(P<0.1)$ and were significantly higher $(P<$ 0.05 ) on $d 1$ of lactation in the control group than in the group supplemented with vitamin A. Plasma and milk $\beta$-carotene concentrations were negatively correlated ( $\mathrm{r}=-0.55 ; P<0.001)$.

Concentrations of retinol plus retinyl ester (Table 5) were affected by vitamin A treatment and time, and there were also significant time $\times$ treatment interactions. Concentrations increased $(P<0.001)$ in both groups during the dry period and up to $d$ of lactation. In the control group, the increase, compared with that of the group supplemented with vitamin A, was delayed $(P<0.001)$, and concentrations were higher $(P$ $<0.001)$ in the middle and end of the dry period as

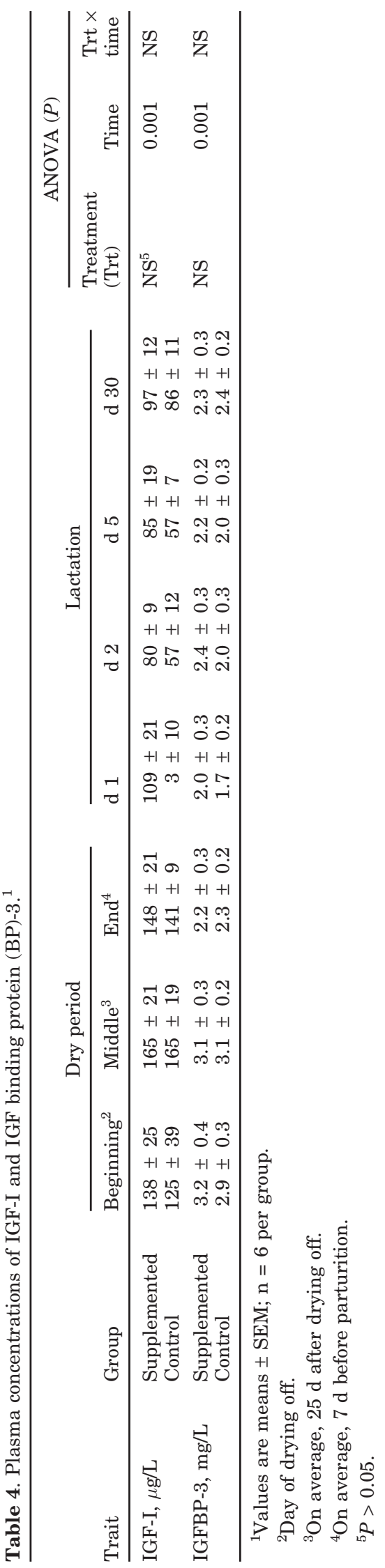

Journal of Dairy Science Vol. 88, No. 5, 2005 
well as on $\mathrm{d} 1$ of lactation $(P<0.05)$ in the group supplemented with vitamin A than in the control group. Plasma concentrations of retinol and milk concentrations of retinol plus retinyl esters were negatively correlated $(\mathrm{r}=-0.54 ; P<0.001)$.

Concentrations of retinyl palmitate (Table 5) were affected by time and increased $(P<0.001)$ during the dry period and up to $\mathrm{d} 1$ of lactation in both groups, but there were no group differences.

Concentrations of atRA (Table 5) were affected by vitamin A treatment, and there was a trend for time $x$ treatment interactions. Concentrations markedly increased $(P<0.01)$ in the group supplemented with vitamin A up to the end of the dry period and then abruptly decreased $(P<0.05)$ on $\mathrm{d} 1$ of lactation, whereas concentrations in the control group reached maximal levels in the middle of the dry period and then transiently decreased $(P<0.05)$ at the end of the dry period. Concentrations at the end of the dry period were higher $(P<0.01)$ in the group supplemented with vitamin A than in the control group, but were not different on $\mathrm{d} 1$ of lactation. Concentrations of 9-cis $\mathrm{RA}$ and 9,13dicisRA/13-cis were below the quantification limit.

Concentrations of Lf (Table 6) were affected by time and in both groups increased $(P<0.001)$ to maximal levels during the middle of the dry period and then rapidly decreased $(P<0.001)$. In the middle and at the end of the dry period, mean Lf concentrations in the control group tended to be higher $(P<0.1)$ than in the group supplemented with vitamin A. Milk Lf and milk IGF-I concentrations were positively correlated $(\mathrm{r}=$ $0.77 ; P<0.001)$.

Concentrations of IGF-I (Table 6) increased in the group supplemented with vitamin $\mathrm{A}$ and in the control group (18- and 34-fold; $P<0.05$ and $P<0.001$, respectively) up to the end of the dry period and then abruptly decreased $(P<0.001)$ on $\mathrm{d} 1$ of lactation. Concentrations tended to be higher $(P<0.1)$ in control cows than in cows supplemented with vitamin $\mathrm{A}$ in the middle and at the end of pregnancy.

Concentrations of IGFBP-3 (Table 6) were affected by time and increased $(P<0.001)$ up to the end of the dry period in cows supplemented with vitamin A and up to $d 1$ of lactation in control cows. The maximal concentration tended to be higher $(P<0.1)$ in control cows than in cows supplemented with vitamin A (8.7and 6.4-fold, respectively). Milk IGFBP-3 concentrations were positively correlated with milk $\beta$-carotene concentrations $(\mathrm{r}=0.56 ; P<0.001)$.

\section{Levels of mRNA of Lf and IGF-I in Mammary Biopsies}

Levels of Lf mRNA (Table 7) were affected by time and were higher $(P<0.001)$ during the dry period than 
Table 6. Lactoferrin, IGF-I, and IGF binding protein (BP)-3 concentrations in mammary secretions. ${ }^{1}$

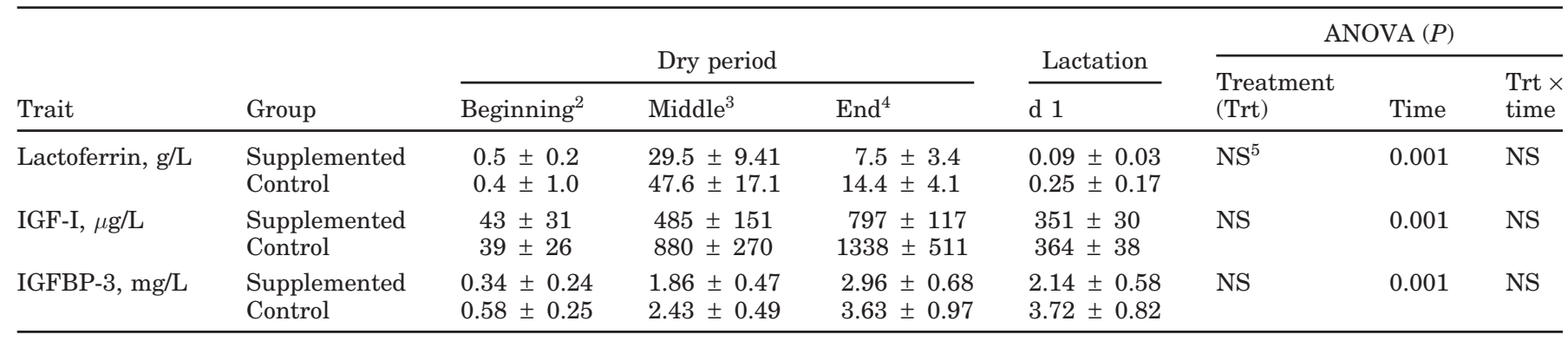

${ }^{1}$ Values are means $\pm \mathrm{SEM} ; \mathrm{n}=6$ per group.

${ }^{2}$ Day of drying off.

${ }^{3}$ On average, $25 \mathrm{~d}$ after drying off.

${ }^{4}$ On average, $7 \mathrm{~d}$ before parturition.

${ }^{5} P>0.05$.

on $\mathrm{d} 1$ of lactation. The IGF-I mRNA levels were higher $(P<0.05)$ during the dry period than at the onset of lactation, but were not significantly different between cows supplemented with vitamin A and control cows.

\section{Histology and Apoptosis in Mammary Gland Biopsies}

Areas occupied by the lumina, interstitial tissues, and mammary epithelia (Table 8) were affected by time. Areas occupied by epithelia did not change significantly during the dry period, but increased $(P<$ 0.001 ) up to $d 1$ of lactation. Areas occupied by stromal tissues did not change during the dry period, but decreased $(P<0.001)$ on $d 1$ of lactation. Areas occupied by lumina decreased $(P<0.001)$ from the start to the middle of the dry period and then markedly increased $(P<0.001)$ up to $d 1$ of lactation. There were no significant group differences with respect to the areas occupied by epithelia, interstitial tissues, and lumina.

Numbers of apoptotic cells (Table 8) in the epithelium were affected by vitamin A treatment and time, transiently decreased in the middle of the dry period
$(P<0.001)$, and then increased up to $\mathrm{d} 1$ of lactation $(P<0.01$ in the group supplemented with vitamin A; $P<0.1$ in the control group). In 7 of 12 investigated cows, there were no apoptotic epithelial cells in the middle of the dry period (3 cows supplemented with vitamin A and 4 control cows, respectively). Numbers of apoptotic epithelial cells on d 1 of lactation were higher $(P<0.01)$ in cows supplemented with vitamin A than in control cows.

Numbers of apoptotic cells in interstitial tissues were affected by vitamin A treatment and tended to be higher $(P=0.13)$ in cows in the treatment group than in the control group in the middle of the dry period and on $d 1$ of lactation.

\section{DISCUSSION}

\section{$\beta$-Carotene, Retinol, and Retinol Metabolites in Plasma and in Mammary Secretions}

A similar plasma $\beta$-carotene status in cows supplemented with vitamin A and control cows expressed a similar intake of $\beta$-carotene, as planned. With $880 \mathrm{IU}$

Table 7. The mRNA levels of lactoferrin and IGF-I in mammary biopsies. ${ }^{1}$

\begin{tabular}{|c|c|c|c|c|c|c|c|}
\hline \multirow[b]{3}{*}{ Trait } & \multirow[b]{3}{*}{ Group } & \multirow{2}{*}{\multicolumn{2}{|c|}{ Dry period }} & \multirow{3}{*}{$\frac{\text { Lactation }}{\mathrm{d} 1}$} & \multicolumn{3}{|c|}{ ANOVA $(P)$} \\
\hline & & & & & \multirow{2}{*}{$\begin{array}{l}\text { Treatment } \\
\text { (Trt) }\end{array}$} & \multirow[b]{2}{*}{ Time } & \multirow{2}{*}{$\begin{array}{l}\text { Trt } x \\
\text { time }\end{array}$} \\
\hline & & Beginning $^{2}$ & Middle $^{3}$ & & & & \\
\hline $\begin{array}{l}\text { IGF-I mRNA, } \\
\times 10^{-7} \text { percent of ubiquitin }\end{array}$ & $\begin{array}{l}\text { Supplemented } \\
\text { Control }\end{array}$ & $\begin{array}{l}3.5 \pm 0.7 \\
5.5 \pm 1.5\end{array}$ & $\begin{array}{l}22.4 \pm 13.7 \\
18.4 \pm 7.6\end{array}$ & $\begin{array}{l}2.3 \pm 0.3 \\
1.4 \pm 0.4\end{array}$ & NS & $<0.05$ & NS \\
\hline
\end{tabular}

${ }^{1}$ Values are means \pm SEM; $\mathrm{n}=6$ per group.

${ }^{2}$ Day of drying off.

${ }^{3}$ On average, $25 \mathrm{~d}$ after drying off.

${ }^{4} P>0.05$. 
of vitamin $\mathrm{A} / \mathrm{kg}$ of BW per d cows of in the group supplemented with vitamin A were supplemented with about 8 times higher amounts than recommended (110 IU/ $\mathrm{kg}$ of BW per d; National Research Council, 2001), but were fed amounts below levels that are considered to be toxic for cattle (National Research Council, 1987). Plasma retinol concentrations in vitamin A-supplemented cows were higher than in controls at the end of the dry period and during early lactation, but differences were relatively small. The liver, which takes up intestinally absorbed retinol and releases it only in amounts that allow the maintenance of relatively stable levels around $300 \mu \mathrm{g}$ of retinol/L (Herdt and Stowe, 1991), was obviously able to maintain retinol homeostasis during the dry period despite a high vitamin A intake. However, plasma retinol concentrations decreased toward the end of the dry period in control cows and at the onset of lactation in cows supplemented with vitamin $\mathrm{A}$, in agreement with other studies and explained by enhanced retinol losses with mammary secretions (Johnston and Chew, 1984; Goff et al., 2002; Van Merris et al., 2004). The decrease of plasma retinol levels in cows in the supplemented group was not only delayed up to the onset of lactation, but was also smaller than in control cows, indicating that the vitamin A supplementation clearly improved the retinol status and homeostasis, although cows in that group secreted more vitamin A in colostrum than did control cows. The higher plasma levels in cows supplemented with vitamin A than in control cows (significant in the middle of the dry period) of retinyl palmitate, which serves as an indicator of retinol absorption (Bitzen et al., 1994), did speak, too, for higher retinol absorption in supplemented cows than in control cows, as expected. However, retinyl palmitate concentrations in mammary secretions during the dry period and in colostrum were not affected by vitamin A supplementation.

Plasma atRA concentrations in supplemented cows and in control cows decreased during the dry period, in agreement with Goff et al. (2002) and Horst et al. (1995). Concentrations in mammary secretions were several times higher than in plasma. This may be explained in part by transport of atRA in the mammary gland against a concentration gradient, enhanced metabolization of retinol to atRA within the mammary gland, or by additional mechanisms. Importantly, plasma atRA concentrations in cows supplemented with vitamin A were not higher than in control cows, despite high intakes of vitamin A by cows in the supplemented group.

Whereas 9-cisRA was always below the quantification limit in this study, this isomer was present in the periparturient period in dairy cows, albeit at very low levels, in another study (Van Merris et al., 2004). On the other hand, 9,13-dicisRA/13-cisRA was present in high amounts in plasma, in accordance with Horst et al. (1995). Our method could not separate RA isomers 9,13-dicisRA from 13-cisRA. However, from data of Horst et al. (1995), it can be postulated that the majority of the HPLC peak was 9,13-dicisRA. Concentrations of 9,13-dicisRA/13-cisRA decreased in both groups during the dry period, possibly because of reduced activity of 9-cis retinol-dehydrogenase, which stimulates 9-cisRA formation and the production of its metabolite, 9,13-dicisRA (Mertz et al., 1997), or because of decreased nonenzymatic isomerization. Our data differ from those of Goff et al. (2002), who described an increase of plasma 9,13-dicisRA around parturition, whereas only a slight increase at parturition occurred in the group supplemented with vitamin A in the present study. Vitamin A supplementation enhanced plasma 9,13-dicisRA/13-cisRA levels. The enhanced metabolization of atRA likely allowed the retention of plasma atRA in vitamin A supplemented cows in the range of cows that were not supplemented with vitamin $\mathrm{A}$.

\section{Lactoferrin in Mammary Secretions and Lf mRNA Levels in Mammary Tissues}

Levels of Lf mRNA were already relatively high at the onset of the dry period, indicating that factors associated with decreasing milk production enhanced Lf mRNA expression. The ensuing decline of Lf mRNA levels during the dry period and at the onset of lactation agreed with Schanbacher et al. (1993). Concentrations of Lf in bovine mammary secretions were high after drying-off, but individual variations were considerable, in agreement with other studies (Welty et al., 1975; Schanbacher et al., 1993). Because changes of Lf mRNA levels were opposite to and small relative to the large changes observed in Lf concentrations, posttranslational factors likely play an important role in the regulation of Lf levels in mammary secretions. Changes of Lf in this study were not in line with the hypothesis that vitamin A enhances Lf levels in mammary secretions and appears to contradict observations from in vitro studies (Baumrucker and Erondu, 2000).

\section{IGF-I and IGFBP-3 in Plasma and in Mammary Secretions and IGF-I mRNA Levels in Mammary Tissues}

A rise of plasma IGF-I concentrations during the dry period, a decrease toward the end of the dry period, 
Table 8. Amounts of mammary epithelia, stroma, and alveolar lumina and number of apoptotic cells in mammary gland biopsies. ${ }^{1}$

\begin{tabular}{|c|c|c|c|c|c|c|c|}
\hline \multirow[b]{3}{*}{ Trait } & \multirow[b]{3}{*}{ Group } & \multirow{2}{*}{\multicolumn{2}{|c|}{ Dry period }} & \multirow{3}{*}{$\frac{\text { Lactation }}{\mathrm{d} 1}$} & \multicolumn{3}{|c|}{ ANOVA $(P)$} \\
\hline & & & & & \multirow{2}{*}{$\begin{array}{l}\text { Treatment } \\
\text { (Trt) }\end{array}$} & \multirow[b]{2}{*}{ Time } & \multirow{2}{*}{$\begin{array}{l}\text { Trt } \times \\
\text { time }\end{array}$} \\
\hline & & Beginning $^{2}$ & Middle $^{3}$ & & & & \\
\hline & & $-\mathrm{Hi}$ & tomorphometry & & & & \\
\hline Epithelium, \% & $\begin{array}{l}\text { Supplemented } \\
\text { Control }\end{array}$ & $\begin{array}{l}14.6 \pm 4.9 \\
14.9 \pm 1.0\end{array}$ & $\begin{array}{l}27.3 \pm 11.4 \\
17.8 \pm 3.8\end{array}$ & $\begin{array}{l}30.1 \pm 2.3 \\
38.5 \pm 4.4\end{array}$ & $\mathrm{NS}^{4}$ & 0.001 & NS \\
\hline Stroma, \% & $\begin{array}{l}\text { Supplemented } \\
\text { Control }\end{array}$ & $\begin{array}{l}70.9 \pm 8.5 \\
79.0 \pm 5.9\end{array}$ & $\begin{array}{l}69.9 \pm 11.2 \\
80.2 \pm 4.1\end{array}$ & $\begin{array}{l}43.5 \pm 5.4 \\
40.7 \pm 5.1\end{array}$ & NS & 0.001 & NS \\
\hline Lumina, \% & $\begin{array}{l}\text { Supplemented } \\
\text { Control }\end{array}$ & $\begin{array}{r}14.7 \pm 7.5 \\
6.5 \pm 3.2\end{array}$ & $\begin{array}{l}2.8 \pm 1.7 \\
2.0 \pm 0.5\end{array}$ & $\begin{array}{l}23.4 \pm 1.0 \\
20.8 \pm 2.0\end{array}$ & NS & 0.001 & NS \\
\hline $\begin{array}{l}\text { Epithelium, } \\
\text { cells } / \mathrm{mm}^{2}\end{array}$ & $\begin{array}{l}\text { Supplemented } \\
\text { Control }\end{array}$ & $\begin{array}{r}3.49 \pm 1.11 \\
2.6 \pm 0.99\end{array}$ & $\begin{array}{l}1.73 \pm 0.86 \\
0.51 \pm 0.35\end{array}$ & $\begin{array}{l}7.87 \pm 3.09^{\mathrm{x}} \\
1.74 \pm 0.36^{\mathrm{y}}\end{array}$ & 0.05 & 0.1 & NS \\
\hline $\begin{array}{l}\text { Stroma, } \\
\text { cells } / \mathrm{mm}^{2}\end{array}$ & $\begin{array}{l}\text { Supplemented } \\
\text { Control }\end{array}$ & $\begin{array}{l}1.97 \pm 0.48 \\
1.34 \pm 0.36\end{array}$ & $\begin{array}{l}4.17 \pm 1.92 \\
1.89 \pm 0.2\end{array}$ & $\begin{array}{l}4.25 \pm 1.40 \\
2.16 \pm 0.56\end{array}$ & NS & NS & NS \\
\hline
\end{tabular}

${ }^{\mathrm{x}, \mathrm{y}}$ Within parameters and between groups, means with different superscripts are significantly different $(P<0.05)$.

${ }^{1}$ Values are means \pm SEM; $\mathrm{n}=6$ per group.

${ }^{2}$ Day of drying off

${ }^{3}$ On average, $25 \mathrm{~d}$ after drying off.

${ }^{4} P>0.05$.

and very low levels at the onset of lactation, followed by an increase during the course of lactation were in agreement with earlier studies (Ronge et al., 1988; Reist et al., 2003). Low plasma IGF-I levels in early lactation have been shown to be mainly a consequence of insufficient energy intake (Ronge et al., 1988; Reist et al., 2003). A rise of IGF-I concentrations in mammary secretions during the dry period, followed by an abrupt decrease within days after the start of lactation has, too, been described before (Malven et al., 1987; Vega et al., 1991). The IGF-I can be produced in the connective tissue of the mammary gland, but is not produced by alveolar epithelial cells (Baumrucker and Erondu, 2000) and thus derives mostly from blood, thereby explaining in part the decrease of plasma IGFI levels during late pregnancy and early lactation (Vega et al., 1991). The decrease of IGF-I concentrations in mammary secretions at the onset of lactation can, to a great extent, be explained by dilution of colostrum and milk (Vega et al., 1991). On the other hand, the increase of IGF-I mRNA expression in mammary gland tissue during the dry period in this study suggests that local production of IGF-I significantly supports the increase of IGF-I in mammary secretions during the dry period and in the colostral phase.

Plasma IGFBP-3 reached low levels in early lactation, as shown previously (Skaar et al., 1991), but changes did not closely follow those of IGF-I. This was surprising because IGFBP-3 transports the bulk of circulating IGF-I, suggesting that IGFBP other than
IGFBP-3 were likely altered and contributed to changes of circulating IGF-I. On the other hand, in mammary secretions, IGFBP-3 roughly followed the pattern of IGF-I.

Vitamin A supplementation did not significantly affect plasma levels of IGFBP-3 or IGF-I. On the other hand, there were significant positive correlations between plasma retinol and plasma IFGBP-3 levels in vivo, as predicted from studies in vitro (Baumrucker and Erondu, 2000), but negative correlations between plasma retinol and milk IGFBP-3 levels. Although these associations suggest functional associations among retinol, IGF-I, and IGFBP-3, the data obtained in the present study did not demonstrate a stimulation of IGF-I and IGFBP-3 production by retinoids, as expected from other studies (Adamo et al., 1992; Shang et al., 1999; Baumrucker and Erondu, 2000).

\section{Histology and Apoptosis in the Mammary Gland}

Histomorphometrical changes in the mammary gland, i.e., areas occupied by epithelial cells, by stromal cells and by lumina during the dry period and until the onset of lactation were in agreement with previous studies (Sordillo and Nickerson, 1988).

Apoptotic cells were found in both alveolar epithelium and mammary stroma, but time-dependent changes were different. The number of apoptotic epithelial cells during the dry period was small, in agreement with Capuco et al. (2003). In our study, the 
relatively high number of apoptotic cells noted in the mammary stroma in the middle of the dry period was consistent with the declining proportion of mammary stroma toward parturition (Wilde et al., 1997). Accumulation of milk in the mammary lumen may cause apoptosis caused by enhanced intramammary pressure and (or) in association with tissue factors, such as IGFBP, whose production may be enhanced (Flint et al., 2001). Importantly, the rise of alveolar epithelial cell apoptosis was more marked in cows supplemented with vitamin A than in control cows, i.e., vitamin A supplementation enhanced the number of apoptotic alveolar epithelial cells. To our knowledge there are no data available showing that retinoids enhance apoptosis rates in bovine. However, in normal human mammary alveolar epithelial cells and in human breast cancer cells, retinoids reduce cell proliferation and enhance apoptosis (Lee et al., 1995; Sankaranarayanan and Mathew, 1996; Seewaldt et al., 1997). The positive correlation between the number of apoptotic bovine mammary epithelial cells and milk retinol levels suggests an implication of retinoids in mammary alveolar epithelial cell apoptosis. The high amounts of supplemented retinol may have exerted a toxic effect.

Interestingly, the highest circulating IGF-I levels during the middle of the dry period coincided with the lowest number of apoptotic alveolar epithelial cells, which was in contrast to Flint et al. (2001), whereas low plasma and colostral IGF-I levels were associated with high numbers of apoptotic alveolar epithelial cells. The inverse relationships between the IGF-I status and the number of apoptotic alveolar epithelial cells are in accordance with IGF-I functioning as a cell survival factor. High numbers of apoptotic alveolar epithelial cells also coincided with relatively high levels in mammary secretions of IGFBP-3, which influence apoptosis. This effect was possibly enhanced in association with the marked decrease of Lf concentrations in mammary secretions, followed by enhanced binding of IGF-I by IGFBP-3 (Baumrucker and Erondu, 2000).

Retinoids are potent inhibitors of proliferation of bovine mammary epithelial cells in association with modified IGFBP-3 production (Purup et al., 2001). In the present study, at the time of parturition, concentrations of retinol and atRA in plasma and of retinol (plus retinyl ester) and atRA in milk were significantly higher or tended to be higher in cows supplemented with vitamin A than in control cows; therefore, it is possible that the vitamin A supplementation decreased alveolar epithelial cell proliferation.

\section{Milk Yield, Milk Composition, and SCC}

The reduced $100-\mathrm{d}$ milk yield caused by vitamin A treatment, although only occurring in wk 12 and 13 , was not expected in view of previous work that documented an increase in milk production after vitamin A supplementation (Oldham et al., 1991). The deviating results could have been at least partially caused by differences in the experimental design. Thus, Oldham et al. (1991) started the supplementation just $2 \mathrm{wk}$ before the expected calving, amounts of supplemented vitamin A were far below those that we fed, the supplementation was continued during the first 6 wk of lactation, and milk yield was only measured for $6 \mathrm{wk}$. It cannot be fully excluded that the reduced yield in the present study was due to toxicity because of relatively high amounts of supplemented vitamin A.

Milk fat concentration tended to be higher in control cows than in cows supplemented with vitamin $\mathrm{A}$, and this led to a significantly higher milk fat production in control cows than in cows supplemented with vitamin A, but reasons for this finding remain unknown. Milk SCC were not influenced by vitamin A supplementation, in agreement with Oldham et al. (1991).

\section{CONCLUSIONS}

This study shows that supplementation with high amounts of vitamin A attenuated the peripartal decrease of plasma retinol concentrations and increased retinol secretion in colostrum. The number of apoptotic mammary epithelial cells in the middle of the dry period was lowest, but increased at parturition and was elevated in vitamin A-supplemented cows. Milk IGFI and Lf concentrations were positively correlated with milk retinol levels, whereas Lf levels in milk were negatively correlated with plasma retinol concentrations, plasma IGFBP-3 levels in milk were positively associated with milk retinol (plus retinyl ester) concentrations, but negatively with plasma retinol levels. However, against our hypothesis, vitamin A supplementation did not modify the concentrations of Lf, IGFBP-3, and IGF-I in plasma and in mammary secretions. Supplementation of vitamin A in amounts at the high end of or above the recommended amounts decreased 100-d milk yield and reduced milk fat yield.

\section{ACKNOWLEDGMENTS}

This study was in part supported by DSM Europe (formerly F. Hoffmann-La Roche, Basle, Switzerland) and in this respect we particularly thank R. Bernet, W. Hunziker, and G. Weber. We further thank S. Wegmann (Schweizerischer Holsteinzuchtverband), Y. Scheppi (Schweizerischer Fleckviehzuchtverband), and M. Reich (Schweizerischer Braunviehzuchtverband) for supporting the search of twin cows within the Swiss cow population. Many thanks go to J. Sturny 
and Y. Aeby and their staff of the Federal Research Station Agroscope Liebefeld-Posieux for help in cow studies. We thank P. Hofmann, DSM Nutritional Products, Kaiseraugst (formerly F. Hoffmann-La Roche, Basle, Switzerland) for retinol and $\beta$-carotene analyses. We thank R. Friis and S. Sauer, Department of Clinical Research, Tiefenauspital, Berne, Switzerland, for advice and support concerning analysis of apoptosis. The technical assistance of C. Morel and Y. Zinden, Division of Nutrition and Physiology, Institute of Animal Genetics, Nutrition and Housing, is greatly acknowledged. We are grateful to D. Greger, presently Division of Nutrition and Physiology, Institute of Animal Genetics, Nutrition and Housing, for critical reading of the manuscript.

\section{REFERENCES}

Adamo, M. L., Z. M. Shao, F. Lanau, J. C. Chen, D. R. Clemmons, C. T. Jr, D. L. Roberts, and J. A. Fontana. 1992. Insulin-like growth factor-I (IGF-I) and retinoic acid modulation of IGFbinding proteins (IGFBPs): IGFBP-2, -3 , and -4 gene expression and protein secretion in a breast cancer cell line. Endocrinology 131:1858-1866.

Bang, P., R. C. Baxter, W. F. Blum, B. H. Breier, D. R. Clemmons, K. Hall, R. L. Hintz, J. M. P. Holly, R. G. Rosenfeld, and J. Zapf. 1995. Valid measurements of total IGF concentrations in biological fluids: Recommendations from the 3rd International Symposium on insulin-like growth factors. Eur. J. Endocrinol. 132:338-339.

Bauman, D. E., and R. G. Vernon. 1993. Effect of exogenous somatotropin on lactation. Annu. Rev. Physiol. 13:437-461.

Baumrucker, C. R., and N. E. Erondu. 2000. Insulin-like growth factor (IGF) system in the bovine mammary gland and milk. J. Mammary Gland Biol. Neoplasia 5:53-63.

Bitzen, U., M. Winqvist, P. Nilsson-Ehle, and G. Fex. 1994. Retinyl palmitate is a reproducible marker for chylomicron elimination from blood. Scand. J. Clin. Lab. Invest. 54:611-613.

Capuco, A. V., S. E. Ellis, S. A. Hale, E. Long, R. A. Erdman, X. Zhao, and M. J. Paape. 2003. Lactation persistency: Insights from mammary cell proliferation studies. J. Anim. Sci. 81(Suppl. 3):18-31.

Flint, D. J., E. Tonner, C. H. Knight, C. B. A. Whitelaw, J. Webster, M. Barber, and G. Allan. 2001. Control of mammary involution by insulin-like growth factor binding proteins: Role of prolactin. Livest. Prod. Sci. 70:115-120.

Goff, J. P., K. Kimura, and R. L. Horst. 2002. Effect of mastectomy on milk fever, energy, and vitamins $\mathrm{A}, \mathrm{E}$, and $\beta$-carotene status at parturition. J. Dairy Sci. 85:1427-1436.

Hennies, M., and H. Sauerwein. 2003. Purification of bovine IGFBP3 and the development of an enzyme immunoassy for the protein. J. Immunol. Methods 28:9-15.

Herdt, T. H., and H. D. Stowe. 1991. Fat-soluble vitamin nutrition for dairy cattle. Vet. Clin. North Am. Food Anim. Pract. 7:391-415.

Horst, R. L., T. A. Reinhardt, J. P. Goff, N. J. Koszewski, and J. L. Napoli. 1995. 9, 13.Di-cis-Retinoic acid is the major circulating geometric isomer of retinoic acid in the preruminant period. Arch. Biochem. Biophys. 322:235-239.

Johnston, L. A., and B. P. Chew. 1984. Peripartum changes of plasma and milk vitamin $\mathrm{A}$ and $\beta$-carotene among dairy cows with or without mastitis. J. Dairy Sci. 67:1832-1840.

Jans, F., and J. Kessler. 1999. Fütterungsempfehlungen für die Milchkuh. Pages 83-112 in Fütterungsempfehlungen und Nährwerttabellen für Wiederkäuer. 4th ed. Forschungsanstalt für viehwirtschaftliche Produktion, Posieux, Switzerland. Landwirtschaftliche Lehrmittelzentrale, Zollikofen, Switzerland.
Lee, P. P., M. T. Lee, K. M. Darcy, K. Shudo, and M. M. Ip. 1995. Modulation of normal mammary epithelial cell proliferation, morphogenesis, and functional differentiation by retinoids: A comparison of the retinobenzoic acid derivative RE80 with retinoic acid. Endocrinology 136:1707-1717.

Lönnerdal, B., and S. Iyer. 1995. Lactoferrin: Molecular structure and biological function. Annu. Rev. Nutr. 15:93-110.

Malven, P. V., H. H. Head, R. J. Collier, and F. C. Buonomo. 1987. Periparturient changes in secretion and mammary uptake of insulin and in concentrations of insulin and insulin-like growth factors in milk of dairy cows. J. Dairy Sci. 70:2254-2265.

Mertz, J. R., E. Shang, R. Piantedosi, S. Wei, D. J. Wolgemuth, and W. S. Blaner. 1997. Identification and characterization of a stereospecific human enzyme that catalyzes 9-cis-retinol oxidation. A possible role in 9-cis-retinoic acid formation. J. Biol. Chem. 272:11744-11749.

National Research Council. 1987. Vitamin Tolerance of Animals. National Academy Press, Washington, DC.

National Research Council. 2001. Nutrient Requirements of Dairy Cattle, 7th Rev. Ed. National Academy Press, Washington, DC.

Nuijens, J. H., H. C. Patrick, C. van Berkel, and F. L. Schanbacher. 1996. Structure and biological actions of lactoferrin. J. Mamm. Gland. Biol. Neoplasia. 1:285-295.

Oldham, E. R., R. J. Eberhart, and L. D. Muller. 1991. Effects of supplemental vitamin $A$ or $\beta$-carotene during the dry period and early lactation on udder health. J. Dairy Sci. 74:3775-3781.

Ontsouka, E. C., C. Philipona, H. M. Hammon, and J. W. Blum. 2004. Abundance of mRNA encoding for components of the somatotropic axis and insulin receptor in different layers of the jejunum and ileum of neonatal calves. J. Anim. Sci. 82:3181-3188.

Pfaffl, M. W., T. M. Georgieva, I. P. Georgiev, M. Hageleit, and J. W. Blum. 2002. Real-time RT-PCR quantification of insulin-like growth factor (IGF)-1, IGF-1 receptor, IGF-2, IGF-2 receptor, insulin receptor, growth hormone receptor, IGF-binding proteins 1,2 and 3 in the bovine species. Domest. Anim. Endocrinol. 22:91-102.

Pfaffl, M. W., S. L. Wittmann, H. H. Meyer, and R. M. Bruckmaier. 2003. Gene expression of immunologically important factors in blood cells, milk cells, and mammary tissue of cows. J. Dairy Sci. 86:538-545.

Purup, S., S. K. Jensen, and K. Sejrsen. 2001. Differential effects of retinoids on proliferation of bovine mammary epithelial cells in collagen gel culture. J. Dairy Res. 69:37-52.

Reist, M., D. Erdin, D. von Euw, K. Tschümperlin, H. Leuenberger, C. Delavaud, Y. Chillard, H. M. Hammon, N. Kuenzi, and J. W. Blum. 2003. Concentrate feeding strategy in lactating dairy cows: Metabolic and endocrine changes with emphasis on leptin. J. Dairy Sci. 86:1690-1706.

Ronge, H., and J. W. Blum. 1988. Somatomedin C and other hormones in dairy cows around parturition, in newborn calves and in milk. J. Anim. Physiol. A Anim. Nutr. 60:168-176.

Ronge, H., J. W. Blum, C. Clément, F. Jans, H. Leuenberger, and H. Binder. 1988. Somatomedin C in dairy cows related to energy and protein supply and to milk production. Anim. Prod. 47:165-183.

Rühl, R., and F. J. Schweigert. 2003. Automated solid-phase extraction and liquid chromatographic method for retinoid determination in biological samples. J. Chromatogr. B Analyt. Technol. Biomed. Life Sci. 798:309-316.

Sankaranarayanan, R., and B. Mathew. 1996. Retinoids as cancerpreventive agents. IARC Sci. Publ. 139:47-59.

SAS. 1994. Introductory Comparison of the GLM and Mixed Procedure. SAS Inst., Inc., Cary, NC.

Schanbacher, F. L., R. E. Goodman, and R. S. Talhouk. 1993. Bovine mammary lactoferrin: Implications from messenger ribonucleic acid (mRNA) sequence and regulation contrary to other milk proteins. J. Dairy Sci. 76:3812-3831.

Seewaldt, V. L., J. H. Kim, L. E. Caldwell, B. S. Johnson, K. Swisshelm, and S. J. Collins. 1997. All-trans-retinoic acid mediates G1 arrest but not apoptosis of normal human mammary epithelial cells. Cell Growth Differ. 8:631-641. 
Shang, Y., C. R. Baumrucker, and M. H. Green. 1999. Signal relay by retinoic acid receptor $\alpha$ and $\beta$ in the retinoic acid-induced expression of insulin-like growth factor-binding protein-3 in breast cancer cells. J. Biol. Chem. 274:18005-18010.

Skaar, T. C., J. R. Vega, S. N. Pyke, and C. R. Baumrucker. 1991. Changes in insulin-like growth factor-binding proteins in bovine mammary sections associated with pregnancy and parturition. J. Endocrinol. 131:127-133.

Sordillo, L. M., and S. C. Nickerson. 1988. Morphologic changes in the bovine mammary gland during involution and lactogenesis. Am. J. Vet. Res. 49:1112-1120.

Sörensen, J. T., and C. Enevoldsen. 1991. Effects of dry period length on milk production in subsequent lactation. J. Dairy Sci. 74:1277-1283.

Van Merris, V., E. Meyer, L. Duchateau, J. Blum, and C. Burvenich. 2004. All-trans retinoic acid is increased in acute-phase related hyporetinemia during Escherichia coli mastitis. J. Dairy Sci. 87:980-987.
Vega, J. R., C. A. Gibson, T. C. Skaar, D. L. Hadsell, and C. R. Baumrucker. 1991. Insulin-like growth factor (IGF)-I and -II and IGF binding proteins in serum and mammary secretions during the dry period and early lactation in dairy cows. J. Anim. Sci. 69:2538-2547.

Vuilleumier, J. P., H. E. Keller, D. Gysel, and F. Hunziker. 1983. Clinical chemical methods for routine assessment of the vitamin status in human populations. Int. J. Vitam. Nutr. Res. 53:265-272.

Welty, F. K., K. L. Smith, and F. L. Schanbacher. 1975. Lactoferrin concentration during involution of the bovine mammary gland. J. Dairy Sci. 59:224-231.

Wilde, C. J., C. V. Addey, P. Li, and D. G. Fernig. 1997. Programmed cell death in bovine mammary tissue during lactation and involution. Exp. Physiol. 82:943-953.

Zinsstag, J., E. Schelling, S. Daoud, J. Schierle, P. Hofmann, C. Diguimbaye, D. M. Daugla, G. Ndoutamia, L. Knopf, P. Vounatsou, and M. Tanner. 2002. Serum retinol of Chadian nomadic pastoralist women in relation to their livestocks' milk retinol and $\beta$-carotene content. Int. J. Vitam. Nutr. Res. 72:221-228. 